\title{
Space for Living Streets of Wroclaw
}

\author{
Marzena Henryka Heliak \\ Chair of Urban Design \& Planning and Settlement Processes, Faculty of Architecture, Wroclaw University of Science and \\ Technology, 50-317 Wroctaw, Poland
}

\begin{abstract}
From the very beginning the street was and still is essential for moving, living and participating in city life. At present we all struggle with communication, traffic and pollution. Now the streets have a different image of their own structure where the car has dominated its space. This research focuses on a bigger picture of the mobility in the city of Wroclaw. Twelve streets including market squares and public places were taken into consideration while providing necessary data for this research. It is very clear that a need of a public space is necessary for a quality of daily life. Also, considering a street as a part of this public space is the main point of my research where I would like to prove that giving the street its importance back, can greatly influence on the development of the urbanized space at the city. I will concentrate on the parts of the city centre of Wroclaw. The major question is how and if we can change and bring our streets back to life. If we can change this we will be able to give our streets deeper meaning in our lifestyle.
\end{abstract}

Key words: Public space, streets, mobility.

\section{Introduction}

From the beginning the street has been a link between different structures and areas building a coherent organism.

Today the image and appearance of the street is changing. It depends on many conditions, i.e.: social, geographical, historical, but also the vision of the city's governors or the main urban planner.

Without a street, it is difficult to imagine a functioning city. An area, without which we could not function and develop, where everyday life intertwines with different needs and activities, expressed through development, giving meaning, importance or prestige to the place. After all, it is also the most important element of access to one's own home.

In recent decades there has been a reflection not only on its perception, but also on its function, position, an important place in the structure of the city. The street, because it is often an ordinary transport route, where traffic flows, ceases to be a perceptible essential space in our everyday life. However, without

Corresponding author: Marzena Henryka Heliak, Ph.D., research fields: social sciences, socio-economic geography and spatial management. E-mail: marzena.heliak@pwr.edu.pl. a street, it is impossible to imagine functioning in everyday life. It is an important element in the life of every community.

For several decades it has been the subject of research, searches and problems in urban structures and beyond.

Also the streets of Wroclaw determine the history of this place, creating over the centuries the cultural richness of the city. This phenomenon is getting even more important today, after so many actions have already been taken to make a street a safe place, offering a possibility of interaction. It is a place of meetings, rest and activity. Streets are a space to live and for life. However, even today we have examples of emptying, abandonment of the street, its social and technical degradation, and devastation of districts or fragments of the city follows.

Many of the above mentioned reflections may not be answered today, but it is worth looking at these phenomena at least in a small part and asking questions about the future and the value of the space of Wroclaw's city streets.

This is the source of important problems for the author, i.e.: to examine the quality of the street space in Wroclaw, its attractiveness, but above all to draw 
attention to the value of this space as being important for and in the everyday life of the city.

In our culture, street and square are still the most important determinants of the composition of the city plan, and their character represents the cultural values with which the residents identify themselves. Polish urban planners, in the Charter of Public Space [1] emphasize the particular importance of the place for satisfying the needs of the local and supra-local community, pointing at the same time to the "collective way of using it". Together with architects, they perceive space in terms of functionality, drawing attention to its architectural and urban resources and values aimed at satisfying the needs and aspirations of the inhabitants.

By definition, which was included in the Charter of Public Space at the Third Congress of Urban Planning of the Polish Society of Polish Town Planners and the Union of Polish Cities in September 2009, space was recognized as a commonly used good, deliberately shaped by man, in accordance with social principles and values - serving the needs of local and supra-local communities, and the public character of space is determined by the collective use of it.

From this definition it is worth emphasizing the accessibility of space and its collective character of use.

Important activities conducive to the protection and rational use of public space were also selected, as laid down in the Charter of Public Space of the Third Congress of Polish Urban Planners, which include: Maximising the value of the city and its real estate by creating high quality public spaces.

- Comprehensive local planning and urban design of public spaces based on the results of urban and architectural competitions;

- Social participation in the creation of tools for shaping and managing public space, with the active participation of local communities in the process of preparing planning documents;
- Protection of cultural heritage and local specificity as special values of public spaces;

- Balance in creating a new public space in relation to the revitalized historical space;

- Fair access to public spaces and minimization of conflicts in their creation and use;

- Shaping public spaces integrating social groups with respect for their different needs and value systems;

- Active use of public spaces and their use for organizing local events [1].

However, the subject of urban space, and urban street in particular, began to gain importance in the literature of the subject, and in the 1960s, with the publication of the tractate by Jacobs [2] in 1964, the need to change the thinking of urban planners about urban space was highlighted more strongly, where the approach to date has been shown to be too disconnected from reality and the needs of the inhabitants.

According to Jacobs [2], plans or urban assumptions met the requirements of Table 1 which presents selected important problems for the development of urban thought in spatial planning.

Designers perceive the cities themselves as a living and constantly changing structure.

On the other hand, in the assumptions for the author's research on Wroclaw Streets, the main goal was to ensure, that the quality of urban street space was visible through the eyes of its inhabitant and to be closer in the future to the needs of the inhabitant, than just the vision of the development of a specific urban tissue resulting from the idea or concept of urban planners and territorial self-government units responsible for the development of the city.

And so that both residents and people responsible for spatial planning, when planning development, analyse the value of space from different perspectives: the obvious: historical or economic ones, but also sociological or psychological, which are gaining importance nowadays. 
Table 1 Selected problems concerning public space.

\begin{tabular}{|c|c|c|c|}
\hline Periods & Research topic & Authors & Main issues \\
\hline 60’s & $\begin{array}{l}\text { "The Death and Life of } \\
\text { Great American Cities" } \\
\text { (1961 r.) }\end{array}$ & Jane Jacobs & $\begin{array}{l}\text { Problems of dying and running on empty streets and spaces in } \\
\text { American cities [2]. }\end{array}$ \\
\hline \multirow[t]{2}{*}{ 70’s } & $\begin{array}{l}\text { The Social Life of Small } \\
\text { Urban Spaces }\end{array}$ & William Holly White & $\begin{array}{l}\text { He started in his research looking for quality space for people. He } \\
\text { inspired other people in the area of sociology as well as in urban } \\
\text { planning to look for there [3]. } \\
\text { Many projects implemented through the Project for Public Spaces } \\
\text { organisation (PPS-was founded in } 1975 \text { and since then has been } \\
\text { very active in the public-private partnership for the quality of } \\
\text { public space). }\end{array}$ \\
\hline & $\begin{array}{l}\text { "Defensible Space" } \\
(1972)\end{array}$ & Oscar Newman & $\begin{array}{l}\text { Problematic safety of the space [4]. } \\
\text { Neighbourhood area being controlled and protected by neighbours } \\
\text { and making easier to recognize strangers and potential danger } \\
\text { behaviours in the neighbourhood. }\end{array}$ \\
\hline \multirow[t]{2}{*}{$\begin{array}{l}80 \text { 's-2000's } \\
\text { and now }\end{array}$} & $\begin{array}{l}\text { Looking for links and } \\
\text { understanding of space } \\
\text { from different } \\
\text { perspectives }\end{array}$ & & $\begin{array}{l}\text { Issues very often included in the current of environmental } \\
\text { psychology - an interdisciplinary branch of science researching } \\
\text { relations between man (his behaviours and feelings) and the } \\
\text { environment. }\end{array}$ \\
\hline & $\begin{array}{l}\text { Internet, urban mobility } \\
\text { and the space of streets } \\
\text { and places }\end{array}$ & & Activation of space. \\
\hline
\end{tabular}

Source: Own elaboration.

\section{Selected Elements Concerning Perception of Streets}

An important part of the research topic undertaken by the author is to broaden the perspective and quote the results of research conducted by SW Research for larger Polish cities, including Wroclaw. The research concerned the importance of the shopping street and its social and economic potential. Ref. [5] includes the results of consumer research conducted in terms of the perception of the concept of a shopping street and supply gaps.

The main four objectives of the report are to redefine the concept of a shopping street, to identify the role of this shopping street format in the development of Polish cities, to analyse the potential of shopping streets and the key factors influencing their development, and to present the strategy of the largest Polish urban centres for the development of shopping streets. The analysis included Warsaw, Krakow, Lodz, Wroclaw, Poznan, Tri-City, Szczecin and Katowice.

For the author the important results were those concerning time spent by residents on a shopping street and in a shopping centre (Fig. 1) [5].
The research involved such issues as preference of choice, realization of needs, satisfaction with the activity and interaction on the shopping street of the residents, compared to the shopping centre. The research has shown, among other things, that the percentage of residents spending over on hour on shopping streets was the highest in Lodz (55\%) and the lowest result was observed among residents of Krakow (24\%). In the case shopping malls the largest number of residents of Warsaw (82\%) and Katowice (81\%) spent more than an hour there, while the lowest result, recorded in the Tri-City, was 63\%. An important element that emerges from this research is to maintain the attractiveness of the shopping streets compared to shopping centres.

Fig. 2 shows how and what elements can affect the importance of the shopping street and what kind of shopping centres are gaining importance today. Very important for a shopping street is its function related to prestige, uniqueness and atmosphere of the place. It is often the main shopping artery in the city, or an important element in the structure of the city of historical importance.

Other important elements are its equipment and 


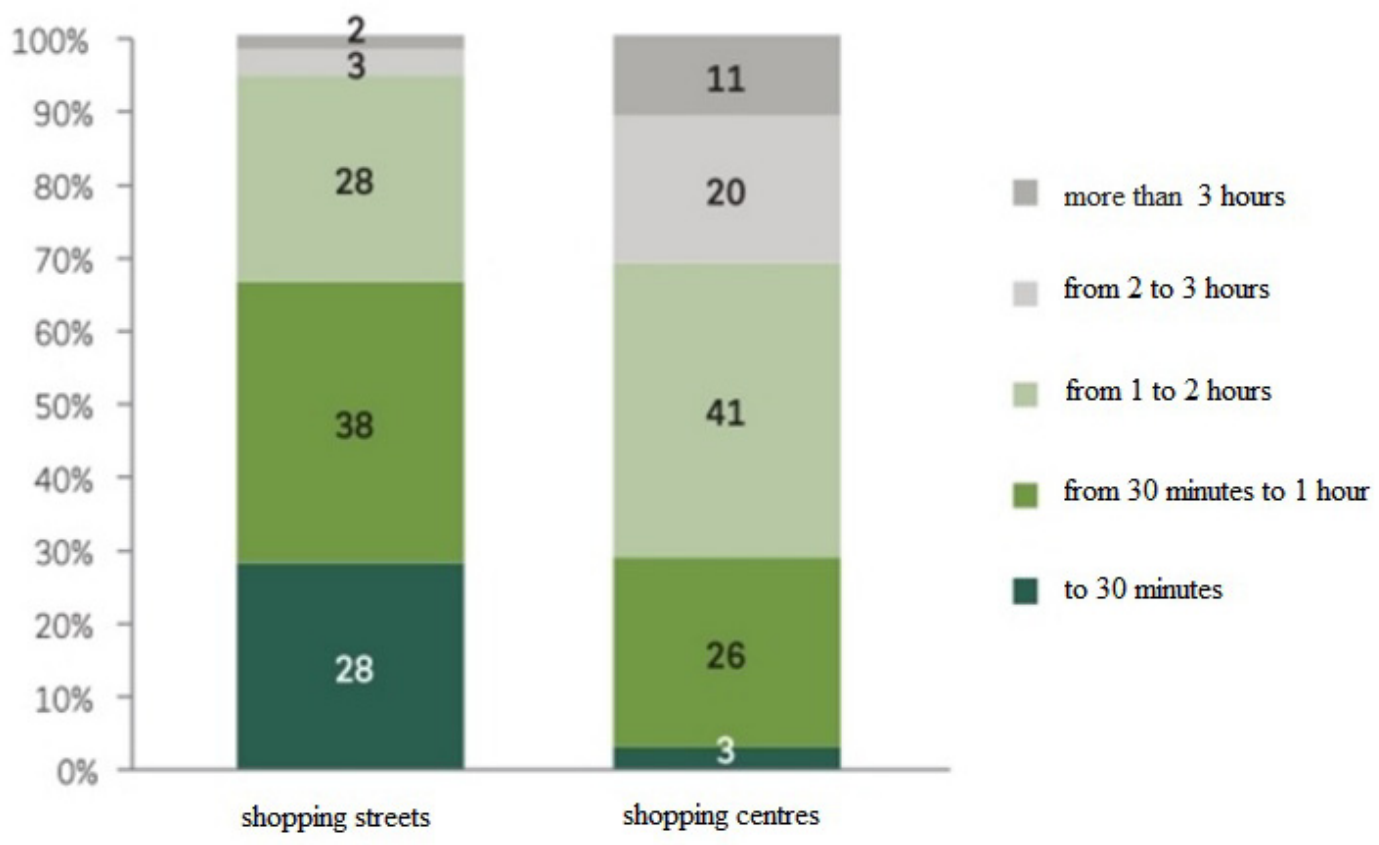

$N=200$

Fig. 1 The time spent by a resident on a shopping street and in a shopping centre in Wroclaw. Source: Ref. [5].

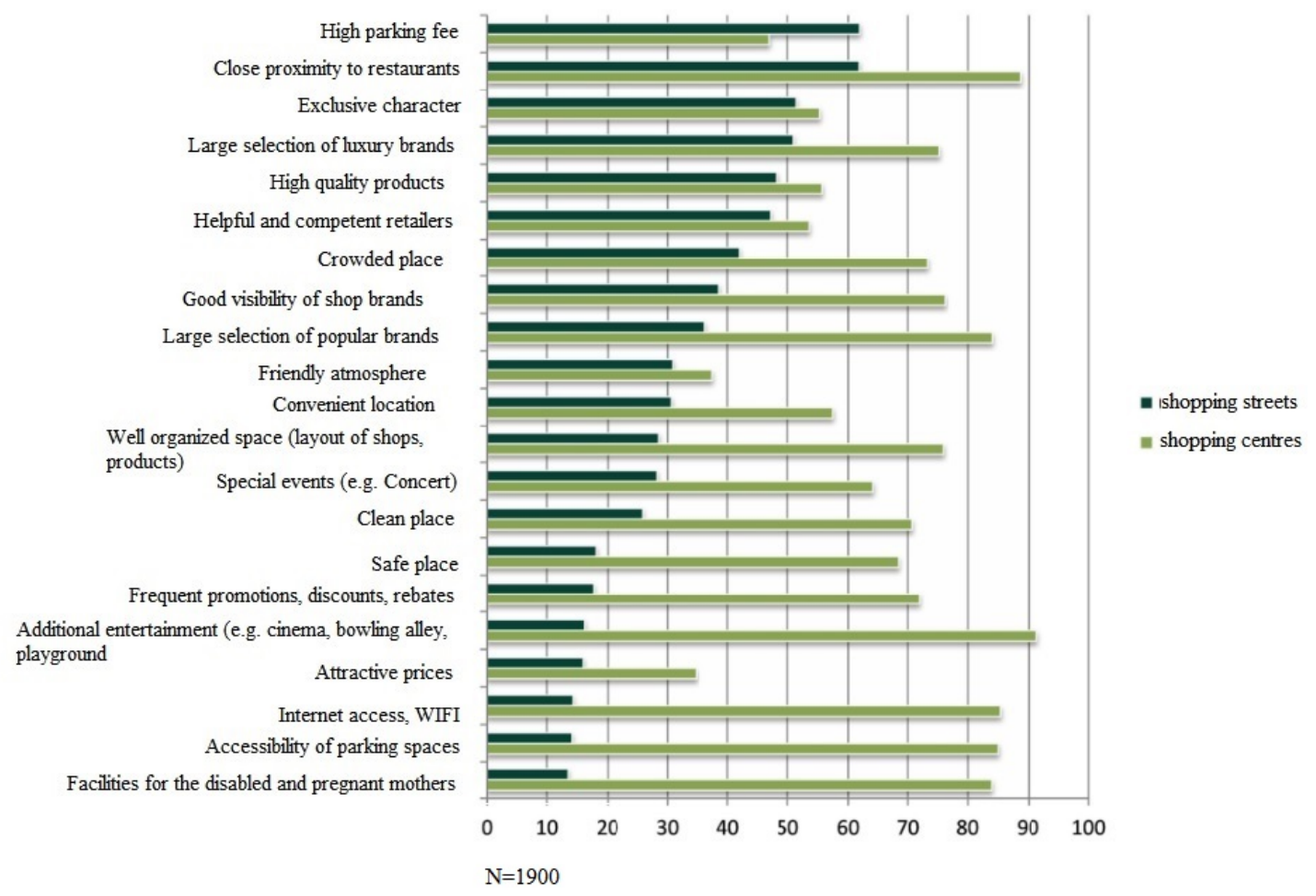

Fig. 2 The attractiveness of the shopping street compared to shopping centres.

Source: Ref. [5]. 
aesthetic and cultural values, as well as the high quality of services and products offered. Shopping centres evolve in the area of infrastructure, equipment with the latest technical facilities and accessibility related to parking spaces.

The conclusion to be drawn from this view is the fact that currently in the surveyed Polish cities a shopping street and a shopping centre, is an area of competition. It is worth emphasizing those elements that strengthen the importance of the shopping street (Fig. 2), i.e.: its openness to interactions and social, cultural values related to the identity, uniqueness of the place, and thus the identification of the residents themselves with the city street, which may affect the value of the space in the city.

The presented material is the first stage for further developed research on the potential and value of the city streets and their revitalisation. The article presents some selected conclusions to illustrate the importance of the topic.

The research concerns the area of the strict centre of Wroclaw and the city centre. It took two months-June-July 2017. The research involved interviews with 260 people on 12 streets, six squares and boulevards of Wroclaw (Fig. 3).

The research concerned the development of an appropriate questionnaire for the research. Questionnaire created for this research had been divided into four theme areas: perception of the street, street equipment, street programme, city furniture. The survey contained 24 questions. The most important concerned:

- Analysis of existing programs (events) on the streets of Wroclaw on selected examples, like St. Anthony's Street, and others;

- Analysis of the needs of residents and the programs being carried out in selected locations indicated by the residents (in the survey);

- An indication of the specific streets recommended to change their current function and features (in the survey).

The research was inspired by the implementation of a project on St. Anthony's Street (Fig. 4), which assumed the creation of high quality space for residents and tourists and the improvement of safety of pedestrians and cyclists in this place. The selected example of the street is important due to its close location and links to the oldest part of Wroclaw with the Market Square. It also creates a communication artery in the area which, as one of the first since 1995, is a place of meetings and cultural events important in the life of the city. By changing the organisation of

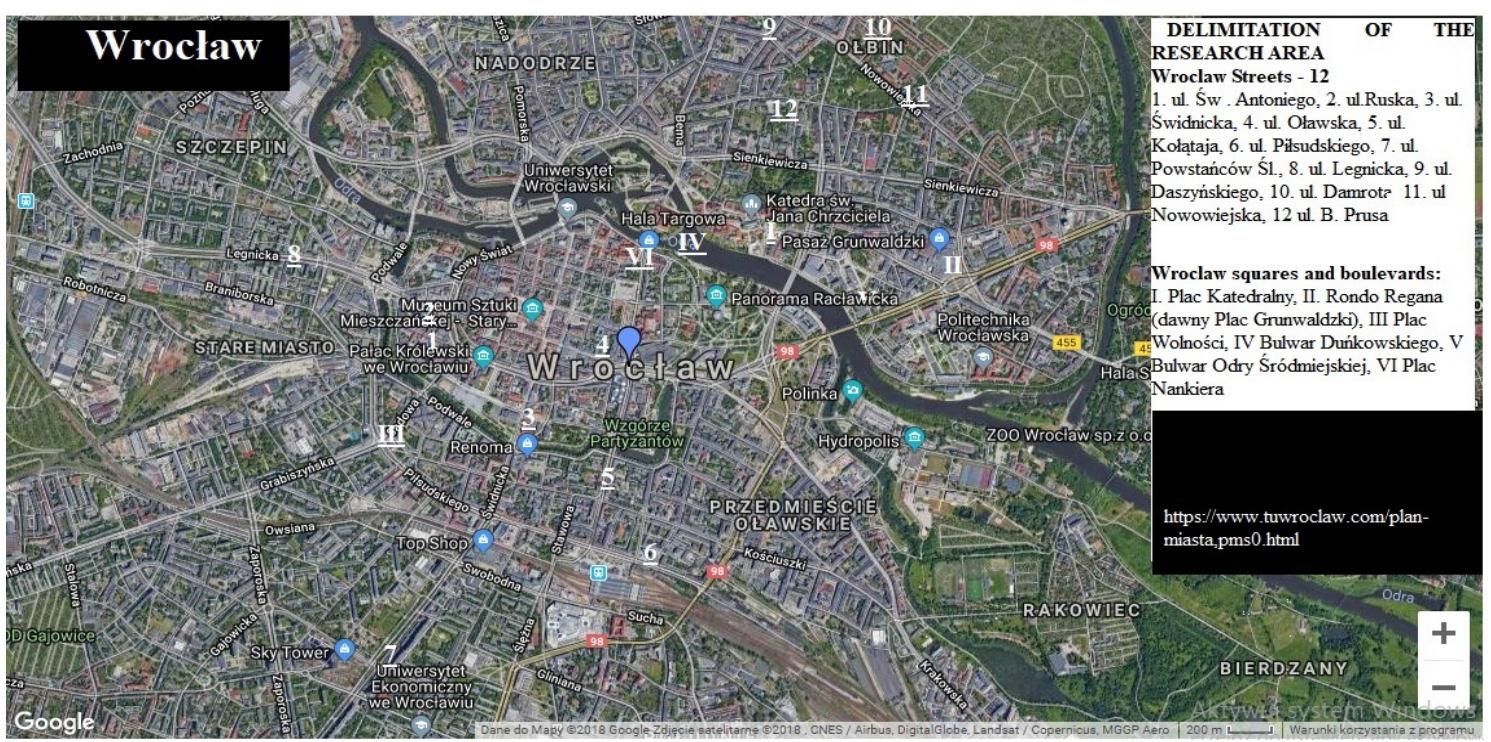

Fig. 3 The area of the strict centre of Wroclaw.

Source: Own elaboration. 


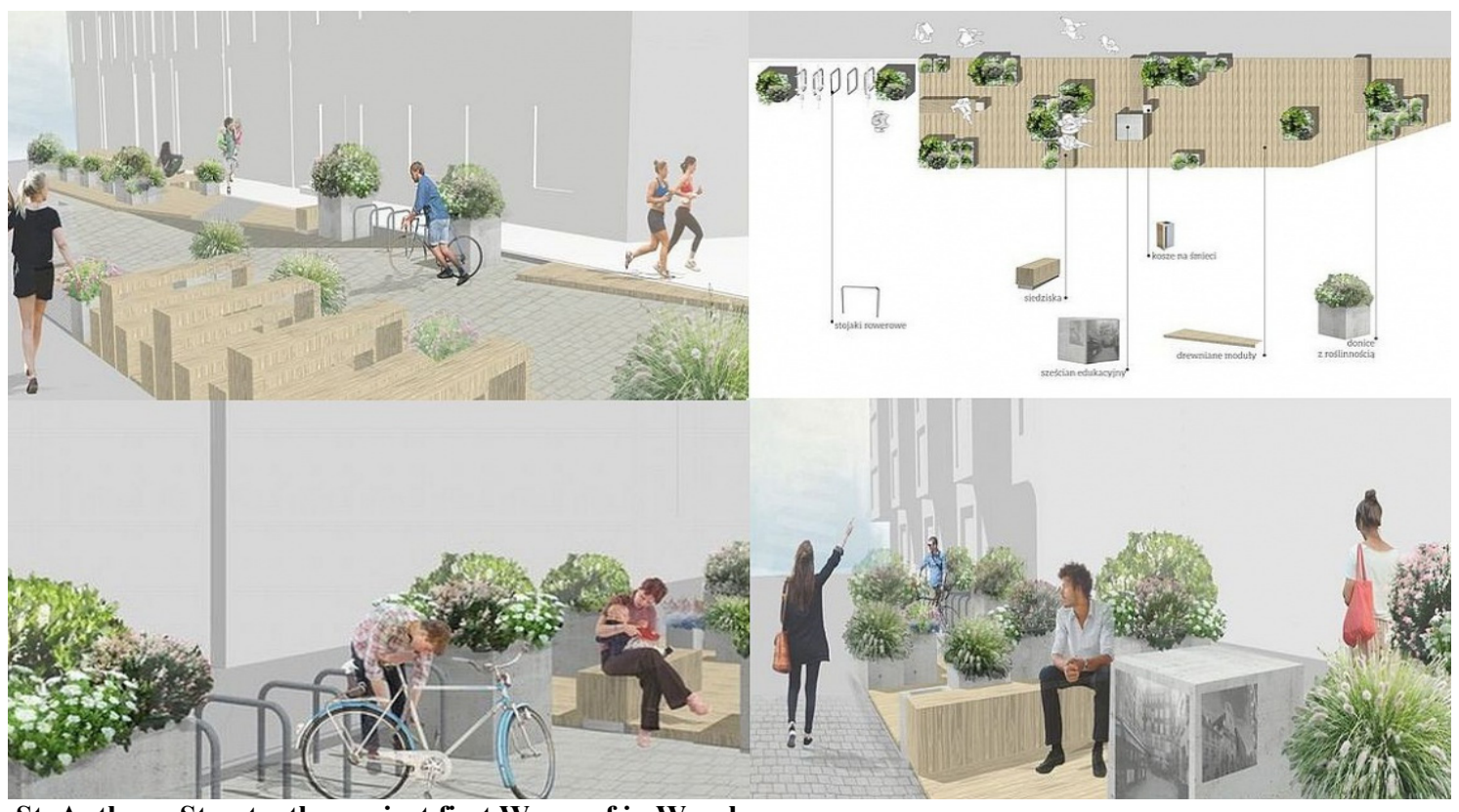

Fig. 4 St. Anthony Street - the project first Woonerf in Wroclaw.

Source: https://www.radiowroclaw.pl/articles/view/50104/Wroclaw-Tak-ma-wygladac-ulica-sw-Antoniego-WIZUALIZACJE.

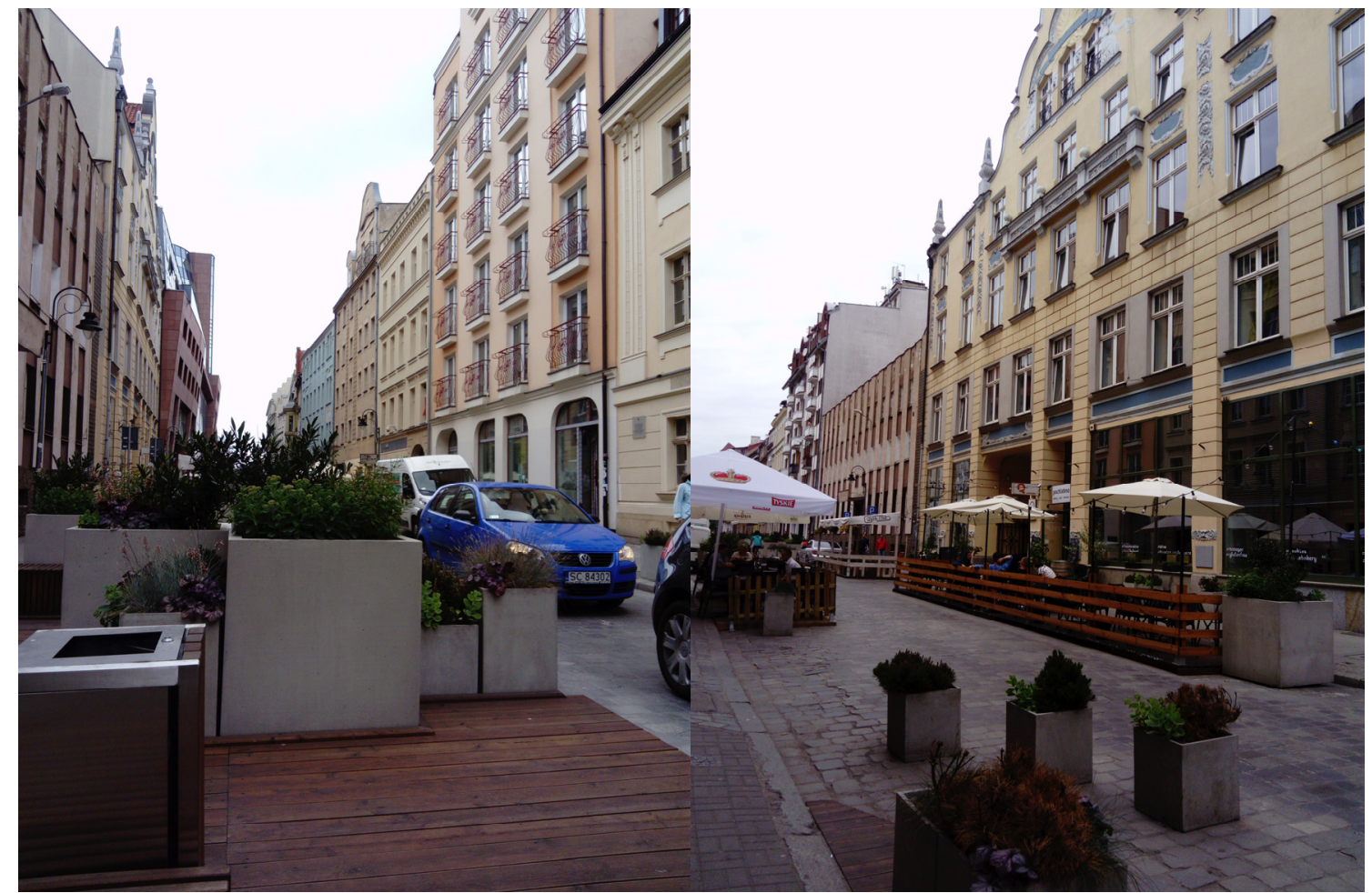

Fig. 5 St. Anthony Street in Wroclaw.

Source: Own elaboration.

traffic and improved equipment in space, St. Anthony's Street became the first Woonerf - the city courtyard.

The creators of the project proposed above all to calm down car traffic. In places where only cars were parked, so-called side islands were placed, i.e. platforms where elements of small architecture were installed (Fig. 5).

The research on St. Anthony Street confirms the need to undertake actions influencing the change of 
image and organisation of street space in cities. The effects achieved were due to the implementation of the assumptions of the change in the spatial organisation of St. Anthony Street.

From a crowded place filled with cars to a place where you can stop and spend some time. $60 \%$ of respondents stated, that the place is safe and there is a possibility of spending free time there.

The street and its surroundings gained both in the organisation of car traffic and other services such as catering, including restaurants and bars, or cafes and other cultural places were strengthened.

From the original research in the above mentioned area of the study, the results are that, however, the level of street safety is not sufficient-Wroclaw's streets are places perceived as dangerous.

Another important observation from the research on the Wroclaw Street is the lack of knowledge and awareness of residents about urban furniture. Most of the answers were limited to the respondents' indicating whether there was a need for lighting, space for bicycles or benches.

\section{Conclusions}

Through a preliminary analysis of the research undertaken by the author, the following conclusions can be drawn. There is a visible need to carry out this type of research in order to strengthen public awareness of the quality of the space and its value not only in cultural but also in social aspect, strengthening participation in the creation of public space development and the influence of a more conscious inhabitant on improving the quality of space in their place of residence.

Another conclusion is to strengthen the educational activities related to understanding of urban space, learning about its history, but also to broaden the knowledge of architecture, urban planning and social issues. This will make it possible to raise awareness on the knowledge of the city, tradition and culture. It will make it also possible to broaden the inhabitants' perception of the shared space as a value and potential for development.

Raising the awareness of both residents and city authorities about the quality of space, its cultural and social richness, and the knowledge of diversity will bring greater attention to space as a unique value - understood as a good place to live.

Let this quote be an inspiration to continue the path that began in the already mentioned 1960s and still exists. May a more conscious look at the street space contribute to the revival of the city space as a good place to live.

Good places should be created by people and for people. They should be valuable and worthwhile. They should also make people want to stay there come back to such a good place.

\section{References}

[1] Bieganski, L., Buczek, G., Gzell, S., Kowalewski, A., Markowski, T., and Cichy-Pazder, E. 2009. "The Charter of Public Space." Presented at the Third Congress of Urban Planning of the Polish Society of Polish Town Planners and the Union of Polish Cities, pp. 7. Accessed September 19, 2018. http://www.tup.org.pl/ download/KartaPrzestrzeniPublicznej.pdf.

[2] Jacobs J. 2014. The Death and Life of Great American Cities (Polish ed.). Warsaw: Architecture Centre Foundation.

[3] Whyte, W. H. 1980. The Social Life of Small Urban Spaces. Ann Arbor, MI: Uniwersytet Michigan.

[4] Newman, O. 1996. Creating Defensible Space. Washington, DC: U.S. Department of Housing and Urban Development Office of Policy Development and Research.

[5] Knap, R., and Staniszewska, A. 2014. Shopping Streets. Analysis, Strategy, Potential. Warsow: Polish Council of Shopping Centres. 